Yönetim, Ekonomi, Edebiyat, İslami ve Politik Bilimler Dergisi,4(1): 7599, 30 Haziran-June, 2019
JOMELIPS - Journal of Management

Economics Literature Islamic and

Political Sciences

e-ISSN :2547-9512

\title{
A Comparative Analysis of the Ukraine Crisis Through the Prisms of Offensive Realism and Liberal Internationalism
}

\author{
Dr. Eray Alım \\ erayalim@hotmail.com
}

\begin{abstract}
In this article, the Ukraine crisis will be analyzed through the prisms of two different International Relations (IR) theories, namely Offensive Realism and Liberal Internationalism. While presenting relevant theoretical discussions, this work will specifically focus on two IR experts, John J. Mearsheimer and John G. Ikenberry, whose names have been associated with these theories. By drawing on the works of Mearsheimer and Ikenberry's for Offensive Realism and Liberal Internationalism respectively, this work will try to make sense of the developments surrounding the Ukraine crisis, while also exploring the explanatory capacities of these two theories through a comparative approach. The insights offered by these theories in explaining Russia's actions and Ukraine's motivation during the crisis will be put to test. In addition, with a focus on the West, this work also aims to offer perspectives through the prisms of these theories on ways to end the Ukraine crisis.
\end{abstract}

Keywords: Ukraine Crisis, Offensive Realism, Liberal Internationalism, Russia, Ukraine

\section{Saldırgan Realizm ve Liberal Enternasyonalizm'in Merceğinden Ukrayna Krizinin Karşılaştırmalı Bir Analizi}

\section{ÖZ}

$\mathrm{Bu}$ çalışmada iki farklı Uluslararası İlişkiler teorisinden yararlanılarak Ukrayna krizinin bir analizi gerçekleştirilmektedir. Bu teoriler Saldırgan Realist ve Liberal Enternasyonalist teorilerdir. İsimleri bu teorilerle özdeşleşmiş olan John J. Mearsheimer ve John G. Ikenberry'nin literatürüne odaklanılarak, gerekli teorik tartışmalar geliştirilmektedir. Saldırgan Realist teori için Mearsheimer, Liberal Enternasyonalist teori için ise Ikenberry'nin çalışmaları bu makalede mercek altına alınmaktadır. Bu teorilere dair birer perspektif sunularak, Ukrayna krizinde öne çıkan hadiselerin bir değerlendirilmesi yapılmaktadır. Karşılaştırmalı bir 
perspektiften, bu teorilerin Ukrayna krizi sırasında yaşanan gelişmelerin anlamlandırılmasında izah kapasiteleri de masaya yatırılmaktadır. Bu yapılırken, kriz sırasında Rusya'nın eylemlerini, Ukrayna'nın ise motivasyonunu anlama ve açıklama noktasında bu teorilerin sunduğu bakış açıları incelenmektir. Ayrıca, Batı odak noktasına alınarak, krize çözüm üretme noktasında bu iki teorinin nasıl bir perspektif sunduğu da ele alınmaktadır.

Anahtar Kelimeler: Ukrayna Krizi, Saldırgan Realizm, Liberal Enternasyonalizm, Rusya, Ukrayna

\section{INTRODUCTION}

The Ukraine crisis is a pivotal event in the post-Cold War international system. It not only affected Russia-Ukraine relations, but also created broader geopolitical impacts embroiling Russia and the west. Prior to the crisis, Ukraine had found itself in a dilemma, which occurred as a result of a decision it had to make between Russia-led Eurasian Economic Union and the European Union. These two organizations had offered Ukraine membership and an association agreement respectively. After months of uncertainty, the then-Ukrainian President Victor Yanukovych's declaration that Ukraine would not sign the association agreement that had been offered by the European Union set the stage for the Ukraine crisis. Following this decision, Ukraine's pro-western social and political actors set in motion a protest movement that resulted in the overthrow of Yanukovich. Soon after this development, Russia, by concluding that its strategic interests came under threat, decided to launch military interventions against Ukraine. These interventions were aimed to achieve two main goals: incorporating Crimea into Russia and controlling Eastern Ukraine's Donbas regions through Russian-backed proxies. Alleged security risks were said to be behind Russia's actions. A sudden change of government in Ukraine was viewed as a threatening development from Russia's perspective, because the installment of a pro-western government in Ukraine indicated the risk of Ukraine's membership to the NATO and Russia's weakening influence over Crimea. Despite Russia's alleged concerns, Ukraine and the west denounced Russia's actions due to the latter's violation of Ukraine's sovereignty and territorial integrity. As tensions developed into a full-scale armed conflict, Ukraine, having already lost Crimea to Russia, put up a stiff resistance in Eastern Ukraine in order not to lose more land, while the west began to impose economic sanctions on Russia as well as providing economic and military assistance to Ukraine. 
Understanding and explaining these developments is necessary, since the Ukraine crisis constitutes a significant turning point in the post-Cold War international system. Some view this event as a sign of the start of a new Cold War (Johnston, 2014). Given this crisis's significance, International Relations (IR) experts have also offered various perspectives on how to make sense of this event by focusing on the interactions between Russia, Ukraine and the west. The purpose of this work is to analyze the Ukraine crisis through the prisms of two different IR theories. These theories are Offensive Realism and Liberal Internationalism, which have diverging views on world politics. It was concluded that, focusing specifically on two theorists in this work, John J. Mearsheimer for Offensive Realism and John G. Ikenberry for Liberal Interventionism, would help produce a more rigorous theoretical discussion. It would be apt to say that the names of these two IR experts have been associated with these two theories, into which their works offer illuminating insights. While developing thematic discussions about the Ukraine crisis, Offensive Realism and Liberal Internationalism's theoretical insights will offer a useful lens to examine this event from different perspectives. This work will adopt an analytical approach in the sense that it will highlight the strengths and shortcomings of these two theories, while examining the details of the Ukraine crisis through their prisms.

\section{IKENBERRY AND MEARSHEIMER}

Liberal theorist John G. Ikenberry has written extensively about the US-led liberal international order over the years. His notion of liberal internationalism is essentially a liberal project promoted by the US across the globe. The aim is to create an international order on the basis of "Open markets, international institutions, cooperative security, democratic community, progressive change, collective problem solving, shared sovereignty, the rule of law. (Ikenberry, 2009b: 71)." The role played by the US to realize this objective is instrumental since it is the leading liberal power that has the capability to drive the liberal internationalist project forward. For Ikenberry, liberal order under American leadership has certain distinctive characteristics. This order is "open and loosely rule-based" (Ikenberry, 2011a: 36) meaning that it is ready to incorporate new states so long as they embrace liberal norms and principles. New states that show an interest in joining the liberal order seize an opportunity to become part of an alliance defined by inclusive rules and norms. Despite the overwhelming power the US retains within the liberal order, coercion is not a feature of this order. Rather, states operating within it pursue 
their political, economic and security interests through reciprocity and bargaining in a framework of multilateralism (Ikenberry, 2009a: 15). This form of liberal governance utilizes complex institutional settings that provide cross-cutting mechanisms to advance interests and help actors pursue agendas in harmony (Ikenberry, 2011a: 36). Ikenberry also points out that when states decide to participate in the liberal order, they do so because they are rational actors, meaning that this order enables them to maximize their interests (Ikenberry, 2009b: 79). Participants utilize various collective goods provided by the hegemon, which is the US. But, liberal hegemon also benefits from the creation of an international order, since it faces less risk and uncertainty in the international system when other states adopt its "vision of world order" (Keohane 1984: 137). Taken together, liberal international order is a mutually beneficial system for all its participants.

The second theorist this work will focus on is John J. Mearsheimer. A prominent Realist theoretician, Mearsheimer developed his theory of Offensive Realism in a book called the Tragedy of Great Power Politics. In that book, Mearsheimer contends that great powers are opportunist and revisionist and that survival necessitates hegemony. According to this theory, great powers must seek to increase their relative power vis-à-vis other states due to perpetual security competition in an anarchic international system. Such views set Mearsheimer apart from defensive realists such that by claiming that offense trumps defence, Mearsheimer argues that states are compelled to maximize their share of world power (Mearsheimer, 2014c: 41). He is especially unconvinced by Waltz's account of great power politics, despite the influence of Waltz' works on Mearsheimer (Mearsheimer, 2009). The divergence can be summed up as follows: whereas Waltz highlights status quo as a key normative feature of great power politics, Mearsheimer claims great power behaviour is characterised by opportunism and revisionism. Mearsheimer also criticizes Defensive Realism, about which he argues that it may be good normative theory, but fails to explain great power behaviour which, he claims, has an offensive characteristic (Mearsheimer, 2006b: 111).

Before he lays out the main hypothesis of his theory in his book, he asserts that "Sound theories are based on sound assumptions" (Mearsheimer, 2014c: 30). In the light of this contention, he presents five bedrock assumptions to describe Offensive Realism's theoretical framework. These five assumptions are: international system is anarchic; all great powers have offensive military capability; states are rational actors; survival is the main aim of states; states' intentions 
about each other cannot be known (Mearsheimer, 2014c: 30-31). Taken together, Offensive Realism paints a starker picture of international politics than does Defensive Realism and urges states to be prepared for worst case scenarios (Mearsheimer, 2014c: 45).

One feature that is common to both Ikenberry and Mearsheimer is the emphasis they place on the dominant role played by powerful states in the international system. Mearsheimer's theory Offensive Realism, apparent in the title of his book The Tragedy of Great Powers, is a theory about great powers. And Ikenberry's almost entire literature deals with the hegemonic position of the US in the international system. Therefore, for both theorists, when some states possess superior power capabilities, this places them at the highest point in the hierarchical ladder (Mearsheimer, 2014: 52; Ikenberry, 2001a: 7). Hence interstate relations take on an asymmetric characteristic.

Ikenberry conceptualizes asymmetrical relations on the basis of hierarchical structures (Ikenberry, 2014b: 87). This can be summed up under two different headings. Firstly, a hierarchical framework may come into being as a coercive sphere of influence, such as the one created by the Soviet Union in Eastern Europe during the Cold War (Ikenberry, 2004: 614). During this period, the Soviet Union employed its hard power capabilities to coerce neighbouring states into its sphere of influence. This was part of the strategy of creating a large empire that extended its reach from the Pacific to Central Europe.

The second type of hierarchical orders described by Ikenberry is liberal hegemonic orders promoted by the US. By comparing alternative formations such as spheres of influences and imperial zones with cooperative and inclusive liberal orders, Ikenberry underscores the distinctive features of the US-led liberal order (Ikenberry, 2001a: 210). Viewed through Ikenberry's prism, economic, political and security ties through which states are locked into a multilateral framework form the basis of liberal international order. An open and inclusive order enables its participants to pursue interests in harmony and interact with each other in a dialogueoriented manner, if and when differences need to be resolved. As opposed to coercive orders in which the hegemon occupies a commanding position, multilateral character of the US-led order gives others "voice opportunities" (Ikenberry, 2011b: 230), meaning that there are channels for smaller states to influence the hegemon (Ikenberry, 2011b: 231). One of the attributes that makes the US a different hegemon is its extensive reach to different parts of the globe. The 
hegemon reaches out to those states that aspire to become members of the liberal order. It provides "public goods of security protection, market openness, and sponsorship of rules and institutions" (Ikenberry, 2009b: 77), should states agree to embrace the hegemon's vision of world order.

Mearsheimer refrains from using the term hierarchy in his analysis of international politics in view of the fact that hierarchy, according to him, is "the ordering principle of domestic politics", (Mearsheimer, 2010a: 79) whereas anarchy is that of international politics. Hence, from his perspective, regardless of power capabilities of states, they all operate under conditions of anarchy and the lack of a central authority makes fear a constant feature of international politics, even for great powers (Mearsheimer, 2014: 2). As opposed to hierarchy, Mearsheimer opts to use the term hegemony in describing interstate relations with asymmetric characteristics. On the other hand, for him, hegemony has relevance only in regional context, because the world is too large for any state to achieve global hegemony (Mearsheimer, 2014: 2). According to Offensive Realism, seizing regional hegemony is essential for security reasons. The need for security is felt more strongly in areas close to great power's home territory (Mearsheimer, 2014b). Given geopolitical sensitivities, great powers seek to exercise maximum control over foreign policy orientation of their neighbours and discourage them to pursue policies that threaten their strategic interests. They also strive to keep extra-regional powers away from their regions because they find it threatening when powerful states operate near their home territory.

\section{ANALYSING THE UKRAINE CRISIS THROUGH THE PRISMS OF MEARSHEIMER AND IKENBERRY}

As for an analysis of the Ukrainian conflict through Ikenberry's conceptual lens, Russia's actions against Ukraine invoke comparisons to those of its predecessor the Soviet Union. In the initial stages of the crisis, Russia's attempt to bring Ukraine into to the Eurasian Economic Union, which it had created with the aim of cementing its ties with neighbouring states, indicates a goal to make Ukraine a part of Russia's regional hegemonic project. In this sense, Russia can be described as a state that seeks to create a hierarchical zone in the post-Soviet space, like its predecessor the Soviet Union, which, according to Ikenberry, sought to construct a coercive sphere of influence and pursued a strategy of institutionalizing its domination in Eastern Europe (Ikenberry, 2004: 613-614). The hegemonic characteristics of the EEU project 
is evident in the fact that it lacks the potential to support Russia economically, thus revealing its geopolitical outlook. For instance, in terms of Russia's export markets, the EEU members' share is only \% 8 (Where Did Russian Federation Export to in 2016?). Moreover, the considerable asymmetry between Russia and its neighbours in economic potential indicates the inevitability of Russian domination within the EEU. For instance, Russia produces $\% 86$ of the total GDP within the union and Russian share in the overall budget of the EEU is \% 88 (GDP Ranking, 2016; Salimov, 2015).

As Ukraine under Yanukovich appeared reluctant to join the EEU and considered accepting the EU's offer to sign an association agreement instead, Russia increased the pressure on Kiev to change track. The aim was to force Ukraine to participate in a Russian-led regional organization. However, Russia's goals failed to deliver the desired results. Following the Ukrainian Parliament's removal of Yanukovich from presidency on 22 February 2014, the new government finally signed an association agreement with the EU. But in the lead up to this event, Russia annexed Crimea and began to support an armed insurgency in Eastern Ukraine. Viewed through Ikenberry's liberal theory, these military actions illustrate all the more clearly the resemblance between Russia and the Soviet Union, which also resorted to the use of force during the Cold War when Eastern European states such as Hungary and Czechoslovakia pursued policies that were disapproved by Moscow.

There is a conceptual similarity between Ikenberry and Mearsheimer in terms of their emphasis on great powers' inclination to establish hieratical or hegemonic orders. But in Mearsheimer's analysis, the normative dimension that forms the basis of Ikenberry's conceptualization with its emphasis on liberal order's distinctive features is absent. Seen from Mearsheimer's prism, because of differences in capabilities, there may exist power disparities which may leave some states in a dominant position vis-à-vis others in a given regional system. When states possess greater capabilities in their region, they must utilize their advantageous position in balance of power to attain hegemony which is necessary for security-related reasons. As emphasized above, seizing regional hegemony is necessary to dissuade potential contenders not to operate in their neighbourhood and regional actors not to engage in acts that are threatening to the interests of the great power. Moreover, unlike Ikenberry who, by focusing on the US, emphasizes the possibility for a great power to create an international order that may extend its reach into different parts of the world, Mearsheimer argues that there are limits to how much a 
great power can expand. He points out that no single state can achieve worldwide domination due to geographic obstacles, more specifically due to the existence of vast oceans (Mearsheimer, 2014c: 41). Therefore, great powers should be content with seizing regional hegemony.

Given Offensive Realism's this description, policies pursued by Russia during the Ukraine crisis should be viewed in the context of a great power's attempt to seize regional hegemony. Mearsheimer emphasizes that states "faces the ever-present possibility that another state will use force to harm or conquer it" (Mearsheimer, 1990: 12). Hence, for Russia or other great powers, survival necessitates seizing hegemony in one's neighbourhood, and if conditions are suitable, controlling territories that are connected to great power's region via land (Mearsheimer, 2014c: 41). The aim is to acquire maximum level of security. Whether the great power seeks to create a sphere of influence or a regional hegemonic order, the purpose must be to maintain a safe neighbourhood.

Viewed through the prism of Offensive Realism, during the Ukraine crisis Russia acted in way that is consistent with the main assumptions of great power politics. Incorporating Ukraine into the EEU was a prerequisite for Russia to bolster its already-dominant position in the post-Soviet space, as Ukraine, with its demographic and economic potential, holds a critical position in Russia's regional politics. Also, a geostrategically significant country on Russia's western flank, Ukraine was a key component for the overall EEU project. Regarding Russia's military intervention against Ukraine, Offensive Realism views this as an expected outcome given the security risks the overthrow of Yanukovich caused for Russia. Ukraine is a key country in Russia's security paradigm and a sudden change of government which involved the replacement of Yanukovich government with a pro-western coalition was a troubling development for Russia (Sakwa, 2016; Mearsheimer, 2014a; Mearsheimer, 2014b; Mearsheimer, 2014c; Mearsheimer, 2014d). Unsure of the potential consequences of a western-leaning government's would-be actions, Russia resorted to the use of force to secure Crimea from Ukraine. Russian military troops' ejection from Sevastopol or NATO's access to Crimea's ports were the main risks that propelled Russia to take military action. Moreover, the employment of force was also aimed to stop Ukraine's drift towards the west, the main goal being the prevention of Ukraine's integration into the NATO. All in all, Russia's actions are in line with Offensive Realism's worst-case scenario assumption. Before a potential threat materialized, Russia sought to 
eliminate it through preventive military actions.

\section{RUSSIA'S SECURITY CONCERNS: A COMPARISON WITH THE US}

While presenting supporting evidence for his views on Russia's military actions, Mearsheimer argues that other great powers such as the US would not have behaved differently, had they faced similar threats in their neighbourhoods (Mearsheimer, 2014b; Mearsheimer, 2014d). As he emphasizes, "major powers are acutely sensitive to threats - especially near their borders — and they sometimes act ruthlessly to address potential dangers" (Mearsheimer, 2014d). Mearsheimer's book is replete with examples which demonstrate the importance great powers attach to acquiring and maintaining regional hegemony. In the Tragedy of Great Power Politics, he traces the process during which the US attained regional hegemony as well as the policies it pursued to protect its strategic interests. The US set out to annex adjacent lands by cleansing the natives and seizing neighbouring countries in a process of continued outward expansion (Mearsheimer, 2014c: 234-246). As laid out in the Monroe Doctrine, the US sought to keep European imperial powers out of the western hemisphere, which gradually paved the way for it to establish itself as the hegemonic power in this region. Regarding the territorial ambitions of the US, Mearsheimer asserts that "the United States was an expansionist power of the first order" (Mearsheimer, 2010b: 388). The US is not an exception in pursuing regional hegemony. For Mearsheimer, other great powers such as the Wilhelmine Germany, the Nazi Germany, imperial Japan, and the Soviet Union all sought to achieve the same goal (Mearsheimer, 2014c: 41-42).

In its recent history, the US, similar to Russia, reacted strongly when it faced threatening developments in its backyard. The gist of interventionist policies pursued by the US in the western hemisphere is laid out clearly by the then-President Reagan. He stressed with reference to Central America that the region "is much closer to the United States than many of the world's trouble spots that concern us... El Salvador is nearer to Texas than Texas is to Massachusetts. Nicaragua is just as close to Miami, San Antonio, and Tucson as those cities are to Washington" (Walt, 1990: 25). Due to geostrategic reasons, the US pursued an active regional policy during the Cold War, manifest in its interventionist policies that resulted in regime changes, overthrow of governments and military coups. As Offensive Realism predicts, despite having secure borders thanks to having relatively weak neighbours such as Canada and Mexico, the US sought 
to exercise maximum control in the entire western hemisphere. This can be seen by looking at the role played by the US in the toppling of the President Salvador Allende of Chile despite this country's considerable geographic distance from the US mainland.

Russia's policies in its region reflect a similar great power behaviour. This country seeks to maintain regional supremacy which necessitates keeping extra-regional powers such as the NATO and the EU away from the post-Soviet space. Given the fact that Ukraine and Russia share a long land border, the latter has geopolitical sensitivities about the former's foreign policy orientation. As Brzezinski stresses, "Ukraine, a new and important space on the Eurasian chessboard, is a geopolitical pivot because its very existence as an independent country helps to transform Russia. Without Ukraine, Russia ceases to be a Eurasian empire" (Brzezinski, 1997: 46). This sums up the indispensability of Ukraine for Russia in the latter's geopolitical calculations. Ukraine may have moderate economic or military capability which makes it a midsize power in Eurasia. Nevertheless, it is still a critical geopolitical player, a status that stems from its geographic location. According to Brzezinski, "Geopolitical pivots are the states whose importance is derived not from their power and motivation but rather from their sensitive location and from the consequences of their potentially vulnerable condition for the behaviour of geostrategic players." (Brzezinski, 1997: 41). Thus, as the main geostrategic player in Ukraine's neighbourhood, Russia pays utmost attention to relations between Ukraine and the west and as the Ukraine crisis demonstrates, it does not refrain from acting offensively, should it conclude that its neighbour is set to pursue policies which would be threatening to its interests. Ikenberry adopts a normative perspective in his analysis of great power politics. Through his theoretical lens, as discussed above, Russia would be seen as an actor that is in pursuit of creating a coercive zone in its region, as its predecessor the Soviet Union. From this perspective, Ukraine would be viewed as a country which a great power seeks to keep in its fold through coercion. Ikenberry also notes that Russia's actions indicate weakness, because the spread of democracy globally is a troubling development for this authoritarian state. Russia, along with China, finds itself in a defensive position, since it observes that increasing number of states in its neighbourhood aspire to join the democratic world. And in the face of this, Russia strives to prevent neighbouring states from moving out of its orbit (Ikenberry, 2014a). Ikenberry's analysis of the Ukraine crisis indicates this line of thinking. He argues that "The economic and political currents in most of the country [Ukraine] are inexorably flowing westward, a trend that 
terrifies Putin. His only recourse has been to strongarm Ukraine into resisting the EU and remaining in Russia's orbit” (Ikenberry, 2014a).

Russia's great power rival the US receives a different treatment from Ikenberry due to its liberal characteristics. Ikenberry examines US foreign policies through an approach based on periodization. He shows that during the Wilsonian phase US foreign policy had an idealistic outlook whose underpinnings were Wilson's principles. Through these principles, Wilson aimed to achieve a number of goals such as ridding the world of imperial practices, promoting democracy and creating international organizations to enable peaceful resolution of interstate disputes (Ikenberry, 2001a). Yet, Wilson's idealistic goal to create a liberal international order failed to materialize on account of institutional inadequacies evident in the failure of the League of Nations (Ikenberry, 2009b: 73-75; Ikenberry, 2009a: 14). After the Second World, the US found itself in a much stronger position, possessing the required material and ideological capacity to build a liberal international order and the institutions associated with it such as the Bretton Woods system (Ikenberry, 2009a: 16-17). Despite acquiring a hegemonic status, Ikenberry argues that the US was reluctant to act like the European imperial powers due to the legacy of isolationalism and exceptionalism, which were at odds with "imperial style domination" (Ikenberry, 2001a: 199). As the conditions after the Second World War necessitated, the US embarked on revitalizing war-wrecked countries in Europe and Asia such as Germany and Japan. To this end, it sought to construct an international order, which required the fulfilment of "functional and operational roles" (Ikenberry, 2009b: 77). This involved establishing rules and institutions that would form the basis of the liberal order, while at the same time providing economic and military support to post-war allies. Hence, hegemony was exercised for the purpose of building an order rather than domination.

Seen through Ikenberry's prism, the distinctive feature of US hegemony lies in the fact that protection and promotion of a liberal capitalist system by the US enabled the fast recovery and development of European and Asian countries after the Second World War. Despite this, according to Ikenberry, policies pursued by the US elsewhere such as in the Middle East and Latin America have been "crudely imperial” (Ikenberry, 2011a: 27). However, regarding Latin America for example, Ikenberry refrains from describing US foreign policy in this region as geared to create or maintain a sphere of influence. Similarly, policies pursued by the US in Central America are not seen as attempts by a great power to enforce its vision of world order 
in its backyard. Ikenberry acknowledges that the US, after the Second World War, has acted coercively at certain times while seeking to discipline (rogue) states (Ikenberry, 2011a: 60). Despite this acknowledgement, the US is not viewed as a coercive military power, because it is ill-suited to be described as such on account of its liberal outlook. Ikenberry does highlight the foreign policy blunders made by the US such as the military interventions executed during the war on terror campaign (Ikenberry, 2002). Nevertheless, it can be inferred from Ikenberry's account that the positive attributes of US-led liberal internationalism way outweigh the negative ones, and even if mistakes are made, these are seen as exceptions or aberrations.

To sum up this discussion, Mearsheimer's analysis of great power politics in regional perspective offers a more objective account due to its indifference to ideological characteristics of great powers. For Mearsheimer, great powers pursue similar goals, which is to achieve regional hegemony and when neighbouring states act in a way that threaten great powers' strategic interests, regardless of their ideological or other attributes, great powers display similar behaviour. The policies pursued by Russia, including military interventions, during the Ukraine crisis is understood in this light. As for Ikenberry, he distinguishes between great powers and also the hierarchical orders which they create. He describes the US and the liberal order it sponsors as having superior characteristics and presents the liberal internationalist project driven by the US as a mutually-beneficial undertaking. Viewed through Ikenberry's lens, competing orders led by Russia and its predecessor Soviet Union are better categorized as coercive zones or spheres of influence. Through Ikenberry's prism, Russia's policies against Ukraine illustrate an actor behaviour that reflects an attempt to bring a neighbouring state into the hierarchical zone of a great power.

\section{UKRAINE'S AGENCY IN THE CRISIS}

As the above discussion illustrates, Mearsheimer's Offensive Realism offers a more objective account than does Ikenberry's Liberal Internationalism in explaining great power politics in regional context. Yet one can also find useful reflections in Ikenberry's works, which can help produce a more thorough assessment of the Ukraine crisis. The fruitfulness of Ikenberry's insights would be clear, if one focuses on the position of Ukraine. Russia's annexation of Crimea resulted in the violation of Ukraine's territorial integrity and its support for an armed insurgency inflicted serious human and economic costs on Ukraine. Moreover, Russia tried 
hard to prevent Ukraine from getting closer to the EU and incorporate it into the EEU. While these events unfolded, it is important to understand how they were viewed from Ukraine's perspective, since it was Ukraine that was subject to Russia's actions.

As Ikenberry belongs to a school of thought known as Liberal International Relations, highlighting one of the assumptions of this theory would be useful. As opposed to Neorealism's inside/outside distinction, which means domestic factors have little explanatory value in describing international politics, the liberal school argues emphasizes the necessity of looking inside states. Ikenberry makes this point by noting that "Governments and domestic actors have incentives and impulses embedded in the deep structures of society to trade, bargain, negotiate, and seek cooperation for joint gain" (Ikenberry, 2011a: 63). Seen in this light, "The liberal claim is that these modernizing forces and movements reinforce each other, pushing and pulling the global system forward in a progressive direction" (Ikenberry, 2011a: 64). For the liberal tradition which Ikenberry is a part of, history should be viewed as unfolding in a linear fashion, indicating the constant progress of a part of humanity that embraces liberal principles. Hence, according this line of thought, liberal system prevails over alternative politico-ideological formations (Fukuyama, 1992). Through adopting liberal norms, states are transformed from within as their politico-administrative arrangements become infused with liberal principles. This internal transformation enables them to connect with other liberal states and become part of the broader liberal international community.

In the light of the above discussion, a glance at the internal dynamics of Ukraine would prove useful. Through Ikenberry's prism, Ukraine's aspiration to join the liberal order would appear to be the driving force behind the Ukrainian people's decision to depose Yanukovich and chart their country's course towards the west (Ikenberry, 2014a). Some of the key developments that paved the way for Yanukovych's removal was his acceptance of economic help from Russia and his consent for Ukraine's participation in the EEU as an associate member. Coupled with his rejection of the EU's offer, these decisions indicated growing risk for Ukraine to move towards Russia's orbit. Given this risk, Ukraine's social and political actors (at least those belonging to the pro-western segment) concluded that their country's interests are best served if Yanukovich is replaced by someone who can deliver on the aspirations of the Ukrainian people, which is to make Ukraine a part of liberal democratic west. An important step was taken in this direction through the signing of an associated agreement with the EU, which occurred 
following Petro Poroshenko's election as president in June 2014. As this discussion demonstrates, a glance inside Ukraine is essential because internal dynamics provide a clear lens in understanding the root causes of the unrest in Ukraine. In short, viewed through the prism of Ikenberry's Liberal Internationalism, Ukraine, similar to ex-Warsaw Pact countries which had previously become members of the liberal democratic west by joining EU and the NATO, wishes to follow this path. Displaying rational actor behaviour, Ukraine, rather than remaining within Russia's sphere of influence, understands that its interests are best served if it forges close ties with the west.

In total contrast to the above discussion, Mearsheimer's Offensive Realism analyses the Ukraine crisis through a structural prism, which entails the omission of internal characteristics of states as well as political and ideological factors. Offensive Realism views states as "blackboxes" (Mearsheimer, 2010a:78) implying that they are considered to be enclosed units interacting with each other in the international system. Offensive Realism asserts that even if internal factors are left out, one can still make sound predictions about international politics. According to this theory, power is not derivative of immaterial factors such as norms or principles, thus discounting the significance of liberalism's normative dimension. For Offensive Realism, power is rather based on material factors such as military capabilities and nuclear weapons (Mearsheimer, 2010c: 2). With respect to the Ukrainian conflict, neither Ukraine as a country nor its internal characteristics would be given weight by Offensive Realism. Mearsheimer, a figure belonging to Structuralist Realist tradition, assumes that knowledge about the 'inside' of a state has little relevance in explaining the 'outside' which is the international system. This is one of the bedrock assumptions of Structural Realism (Mearsheimer, 2010a: 83).

A system-level examination, though, provides only limited analytical scope. On a closer look at the Ukrainian conflict, it would be seen that the ethnic composition of Ukraine as well as social, cultural and historical factors are key variables in understanding the root causes of the tensions in the country as well as the reactions given by different segments of the Ukrainian society. Regarding Ukraine's historical background, without understanding the influence of Habsburg and Russian empires on Ukraine's sociocultural makeup, it would not be possible to explain why eastern and western regions of Ukraine reacted differently to the crisis (Darden, 2014). It would also not be possible to explain why eastern and western parts of the country 
have different attitudes towards Russia. We cannot understand these aspects through Mearsheimer's theory. Because, as he himself admits, his "theory pays little attention to individual and domestic political considerations" (Mearsheimer, 2014c: 10-11). Therefore, focusing solely on military capabilities of great powers leaves out other important factors which may be determinative.

As well as omitting the 'inside' of states, Mearsheimer's theory also discounts the agency of small states in world politics. As he points out "The sad truth is that might often makes right when great-power politics are at play. Abstract rights such as self-determination are largely meaningless when powerful states get into brawls with weaker states" (Mearsheimer, 2014d). As this remark indicates, it is the powerful states that determine the direction of world politics. As a leading name in Structural Realist tradition, Waltz adopts a similar view by arguing that "In international politics, as in any self-help system, the units of greatest capability set the scene of action for others as well as for themselves (Waltz, 1979: 72). He also contends that "It would be as ridiculous to construct a theory of international politics based on Malaysia and Costa Rica as it would be to construct an economic theory of oligopolistic competition based on the minor firms in a sector of an economy" (Waltz, 1979: 72).

One runs the risk of producing inaccurate predictions about international political developments if the agency of small powers is neglected. For example, the reason for Russia to encounter an intractable conflict in Eastern Ukraine cannot be sufficiently explained through Offensive Realism (and Structural Realism more broadly), because, by paying no attention to Ukraine, this theory tells us little about the motivation of Ukraine to resist Russia and its proxies. As the conflict in Eastern Ukraine's Donbas region has entered its sixth year, Ukraine's determination to restore its territorial integrity despite facing Russia military threat reveals that Ukraine's agency needs to be factored in, while evaluating the prospects as to how the Ukraine crisis might come to an end.

A glance inside Ukraine would show that throughout the post-Cold War period, regardless of who served as president, be them pro-western politicians such as Leonid Kravchuk and Victor Yushchenko or (despite an inaccurate description), relatively pro-Russian Yanukovich, Ukraine has consistently pursued a cautious policy towards Russia due to the fear of falling under latter's influence. Ukraine's motivation to wage a determined struggle in Eastern Ukraine derives from 
this sensitivity. Losing Crimea had been a traumatic experience for Ukraine and given the risk of suffering greater land loss, it remained adamant about restoring its sovereignty in Donbas. In short, Offensive Realism offers a partial explanation of the crisis due to disregarding Ukraine's agency.

\section{WAYS TO RESPOND RUSSIA FOR ITS ACTIONS AGAINST UKRAINE}

Through the lens of the two theories used in this work, this section will offer an account on ways to respond Russia for its actions against Ukraine. Before doing this through Ikenberry's lens, a short description of his views on the current liberal international order as well as the position of the US in it is due. As seen in his earlier works, Ikenberry was inclined to consider the US a global hegemon (Ikenberry, 2001b: 20). From his book Liberal Leviathan onwards, however, he began to question the hegemonic position of the US, given the consuming military interventions in Iraq and Afghanistan, the 2008 financial crisis as well as the fact that rising powers such as China, India and Brazil became more influential international players, thus signalling the end of US supremacy (Ikenberry, 2015b 409). He calls the new situation a "crisis of authority, which means a "crisis of governance" (Ikenberry, 2011a: 6). Despite setbacks, liberal order may overcome the difficulties it encountered over the last decade by pursuing certain courses of action. First and foremost, according to Ikenberry, the US should "renegotiate hegemonic bargains with other states" (Ikenberry, 2011a: xiv). This requires more burdensharing among liberal powers (Ikenberry, 2011a: 10) and a commitment that international norms, rules and institutions will be adhered to. These proposals reflect the need for the replacement of unilateralism with multilateralism.

Despite the negative developments faced by the US and the liberal order it leads, Ikenberry still highlights the positive aspects of liberal internationalism and argues that the crisis of the liberal order is "- at least to some extent - a crisis of success" (Ikenberry, 2015b: 400). Behind the success story lies attempts by the US to create an international order built upon "global openness" (Ikenberry, 2015b: 409) which states such as China, India and Brazil utilize to achieve fast growth and progress. In this respect, setbacks should not be construed as signs for the end of the liberal order. As Keohane argues with respect the US, international regimes created by the hegemon may outlive the hegemon itself (Keohane, 1984: 100-101). Similarly Ikenberry points out that liberal international order is still the dominant system with its well- 
functioning rules and institutions, which outperformed even the hegemon itself, which is the US (Ikenberry, 2015a: 452). This captures the essence of Ikenberry's account of US hegemony: the liberal system designed by the US continues to deliver public goods for states, even if the US may no longer enjoy the same predominant position in the international system. Based on this view, despite the crisis of the liberal order, Ikenberry asserts that, liberal principles and institutions are still functional in the post-hegemonic order (Ikenberry, 2015a: 452). Therefore, liberal internationalism with its ideological underpinnings still retains its dominant position and continues to offer the most ideal international order. This is because rising powers lack the vision to offer alternative international orders and continue to act through and within the liberal international order to advance their interests (Ikenberry, 2011b: 243).

However, Ikenberry singles out Putin's Russia as the only exception on the grounds that this state may embark on creating a post-liberal order (Ikenberry, 2015a: 452). The Ukraine crisis, as well as Russia's attempts to create a hierarchical regional order in the post-Soviet space, serve to reinforce this view. The above argument shows that Ikenberry's theory distinguishes between hierarchical orders and considers Russia, as well as its predecessor Soviet Union, as a coercive power in Eurasia. Ikenberry himself has not spell out his view on how to respond to Russia for its actions during the Ukraine crisis. But since he believes that "liberal ascendency is not over," (Ikenberry, 2011a: 338) and the crisis of the US-led international order is not the crisis of liberal internationalism, one can extrapolate that there is still a role to play by liberal powers to prevent challengers from posing a threat to liberal international order. It is also incumbent on liberal powers to reach out to those states that aspire to join the liberal west.

From the moment Ikenberry began to discuss the emergence of a post-hegemonic order, he ascribed the US an organizational role. By comparing the realist concept of "pole" with the concept of "hub" he argues that, by taking on the role of an organisational hub which "other states connect to," the US "provides the organizing infrastructure of international relations [...] within the wider global system" (Ikenberry, 2011b: 217). Given this organisational capability, one can argue that there are still tools at the disposal of the US, along with its partners, that could be used against Russia for its threatening behaviour. For instance, the US is still the hub of global financial and banking activity, and through dollar it retains a leverage to influence global trade and world financial markets. In a nutshell, the US derives its influence from its ability to help maintain "the global economic status quo (Ikenberry, Wohlforth and Brooks, 
2012: 44). Ikenberry, Wohlforth and Brooks describe the US as the facilitator of "macrolevel structuring" of the global economy" (Ikenberry, Wohlforth and Brooks, 2012: 44). The US is also able to translate its economic power into political leverage to enforce its decisions.

During the Ukraine crisis, the US utilized its political influence and economic power while devising measures against Russia. Such measures include forcing European companies not to participate in energy projects with Russia and placing sanctions on Russian firms and individuals with close ties to the Kremlin (Nienaber, 2019). Through these measures, the US has also taken a supportive position towards Ukraine which the US believes faces Russian aggression (2017). The US support for Ukraine would not be unexpected, as the US had also offered help to Russia after the dissolution of the Soviet Union. Ikenberry reminds that "When the Soviet Union collapsed, the American-led order offered a set of rules and institutions that provided Soviet leaders with both reassurances and points of access (Ikenberry, 2011b: 234235). As Russia indicated its willingness to become part of the liberal international order in the first years of the post-Cold War period, the US, and its western allies, offered economic assistance and also enabled Russia's integration into organizations such as the G7. Viewed through Ikenberry's prism, given liberal states' inclination to embrace nations that show an interest in joining liberal international order, it should be expected of the west to offer Ukraine the required assistance in the latter's efforts to westernize. The west has taken certain steps in this regard. These include providing economic assistance to Ukraine via the IMF, strengthening NATO-Ukraine relations and encouraging Ukraine to undertake EU-inspired reforms to modernize its politico-administrative system. These measures are all in line with the liberal internationalist project as they pave the way for an aspiring state to join the liberal order.

Military assistance to Ukraine is especially important given the ongoing armed conflict in Eastern Ukraine. In the provision of such assistance, NATO holds a key position. Evaluating the NATO's functioning through a liberal internationalist lens, Ikenberry views this organization's continued role in the post-Cold War world in a positive light for two reasons. He argues that "the expansion of NATO in Eastern Europe and the former Soviet sphere was a critical step [...], a movement driven as much by liberal aspirations for assisting and integrating newly democratic states as by a traditional logic of security protection" (Ikenberry, 2011b:238). As he indicates, through the admittance of ex-socialist states into the NATO (as well as the EU), new nations were integrated into the liberal order, thus expanding the scope of liberal 
internationalism. Furthermore, the security architecture designed around an expanded NATO contributed to a stable and united Europe after the Cold War.

So as to reach out to those states that aim to forge stronger ties with the liberal order, liberal powers are expected to offer military support, if not NATO membership, to Ukraine. The necessity of this policy is evident in Ukraine's attempts to move away from Russia's fold, which, as a crucial step, requires restoration of its territorial integrity and denying Russia a sphere of influence inside its borders. Indeed, albeit non-lethal, NATO's assistance to Ukraine in a wide range of areas in a bid to bolster its military performance and readiness demonstrates, if partially, the west's supportive policy towards Ukraine (2018). Moreover, the supply of Javelin anti-tank missile systems by the US to Ukraine signals a move from non-lethal to lethal aid, illustrating NATO's leading power's willingness to give Ukraine firmer military support. The UK, another influential liberal power, has joined the US in providing naval support to Ukraine, which had experienced a confrontation with Russia in the Sea of Azov (Peterson, 2018).

Such steps come with a risk though. Encouraged by western support, if Ukraine embarks on a military campaign to root out Russia's proxies, there is a high likelihood for a stronger Russian military response, creating the risk of a serious escalation. As Mearsheimer cautions, great powers are always sensitive to threats in their neighbourhood (Mearsheimer, 2014d). So, attempts viewed by Russia as provocative may lead to a broader geopolitical crisis. As the Ukraine crisis has led to a renewed Russia-West tensions, which opened a new phase in bilateral relations and which some view as the beginning of a New Cold War, liberal powers are justifiably distressed that Russia's actions could create a broader geopolitical instability. In this respect, although avoiding measures that would lead to a military confrontation would be the rational course for the west, there are still tools in the west's disposal to be used against Russia in order to discourage it from pursuing an aggressive path. Adopting economic restrictions in energy and finance sectors, which the west introduced with the start of the armed conflict in Ukraine in 2014, would suffice in demonstrating to Russia that prolonging the conflict when it is under economic distress would not serve its interests.

Mearsheimer offers a more cautious approach vis-a-vis Russia. He sees the primary causes of the conflict in the west's institutional expansion, which, he claims, constitutes a threat to 
Russia's strategic interests (Mearsheimer, 2014d). Mearsheimer's earlier remarks on Russia were more balanced, which can be seen by looking at his analysis of Russia-Ukraine relations in early 1990s. When the possibility of Ukraine surrendering its nuclear arsenal surfaced, Mearsheimer had argued against it in 1993 on the grounds that, as he predicted, relations between Ukraine and Russia would deteriorate over time (Mearsheimer, 1993. See also Mearsheimer, 2010c). Hence Ukraine required a powerful deterrent against Russia to guarantee its security (Mearsheimer, 1993). After Ukraine agreed to remove its nuclear weapons, Mearsheimer seems to have revised his views on Russia-Ukraine relations. One can infer from his remarks on the Ukraine crisis that Russia's militarily hegemonic position became firmly established following Ukraine's denuclearization in the post-Soviet space. Under new conditions, both regional actors such as Ukraine and extra-regional actors such as the NATO and the EU must pay heed to Russia's geopolitical sensitivities before they set their policies in the post-Soviet space (Mearsheimer, 2014a; Mearsheimer, 2014d).

Regarding policy advices of Offensive Realism on the crisis, Mearsheimer recommends a more prudent approach. According to Mearsheimer's theory, hegemons such as the US, which is the dominant power in the western hemisphere, must seek to prevent rival great powers from seizing hegemony in their regions (Mearsheimer, 2014c: 41). The reason to pursue this policy is that once having secured regional dominance, the great power will likely cause trouble for the hegemon in its own region (Mearsheimer, 2014c: 41). Mearsheimer analyses US-China relations in the light of this theoretical hypothesis. Seeing China as the most serious contender to the US, he anticipates that the US will strive to prevent China from seizing regional hegemony in the Asia-Pacific region (Mearsheimer, 2006a; Mearsheimer, 2010b).

However, for Mearsheimer, Russia does not have the required power capabilities to pose a threat to the US. This is evident, according to him, in Russia's negative economic and demographic dynamics which impair its ability to reclaim the status of the Soviet Union (Mearsheimer, 2006b: 119-120; 2014d). Mearsheimer compares Russia with China and Germany, both of which, he says, surpass the former in economic potential (Mearsheimer, 2006b: 119). Emphasizing that Russia has legitimate security concerns given Ukraine's geostrategic significance (Mearsheimer, 2014d), Mearsheimer stresses the need to pursue cautious policies towards Russia. According to him, certain commitments must be made by the west to help defuse the crisis. As an important de-escalatory measure, he emphasizes the 
necessity of assuring Russia that Ukraine will not join western institutions. This precondition must be fulfilled so as to make Ukraine a neutral country, which according to him, is essential to bring an end to the ongoing crisis. Seen from this perspective, attempts such as arming Ukraine or offering NATO membership would be dangerous, as they would provoke Russia (Mearsheimer, 2015).

Once Ukraine's neutrality is secured, Mearsheimer says that the IMF, the EU and the west in general as well as Russia must all help Ukraine to solve its economic problems, thus enabling it to become a viable state (Mearsheimer, 2014d). The overall point is that Ukraine's interests will be better served should it remain a neutral state, one that can interact with both east and west. This proposal, however, is in contradiction with Mearsheimer's theory. One of the five main assumptions of Offensive Realism is that states' ultimate intentions cannot be known (Mearsheimer, 2014c: 3). Therefore, there is no guarantee that Russia will respect Ukraine's neutrality, should it be secured, and will not seek to bring Ukraine into its geopolitical orbit with the passing of time. As states operate in an anarchic system, there is no central authority that could serve as a guarantor for Ukraine. Ukraine's scepticism towards Russia reflects this awareness, since, as stated above, it has remained wary of Russia's intentions throughout the post-Cold War period under different administrations.

\section{CONCLUSION}

This work has sought to examine the Ukraine crisis through a comparative theoretical approach. By focusing on Liberal Internationalist John Ikenberry's and Offensive Realist John Mearsheimer's literature, the main assumptions of these two theories were presented and then they were applied to thematic arguments which were developed in the following sections. While discussing the Ukraine crisis, this work has also sought to shed light on the strengths and limitations of these two theories. The two theoretical approaches employed in this work have one feature in common which is that they attribute significant weight to great powers in explaining world politics. With their stress on concepts such as hierarchy and hegemony, these two theories underscore the importance of understanding the characteristics of asymmetric relations in international politics. Asymmetry is a consequence of differences in power capabilities among states. But power is not understood the same way by these two theories. Whereas Liberal Internationalism highlights the importance of immaterial factors such as norms 
and principles as well as material factors, Offensive Realism focuses solely on material capabilities of states (more specifically their military capabilities and nuclear arsenals).

As discussed in this study, this difference sets them apart in their exploration of the politics of powerful states (great powers). Ikenberry distinguishes between great power politics. According to his analysis of US foreign policy, the attempt by the US to establish a liberal order is indicative of a great power seeking to create a cooperative international order, one that is based on norms, principles and rules. On the other hand, through Ikenberry's theoretical lens, Russia would be seen as a coercive state trying to create a hierarchical regional order (or a sphere of influence). Russia's actions against Ukraine (pressuring it to join the EEU and carrying out military interventions in the aftermath of the ouster of President Yanukovich) would demonstrate the coercive characteristic of its regional policies. However, interventionist policies pursued by the US in the western hemisphere, albeit acknowledged, are not considered as a great power seeking to create a hierarchical regional order or imposing its vision of world order in its backyard. As for Mearsheimer's Offensive Realism, this theory would view Russia's actions against Ukraine as an expected great power behaviour. Mearsheimer argues that the US acted similarly when it faced regional developments that threatened its strategic interests. Through Offensive Realism, interventionist policies pursued by the US in the western hemisphere have strong similarities to those pursued by Russia against Ukraine. On the basis of Mearsheimer's contention that security necessitates seizing regional hegemony, one can make better sense of Russia's actions during the Ukraine crisis given the former's geopolitical sensitivities and security needs. Russia's actions throughout the crisis is better understood as a great power trying to ensure that a neighbouring state remains in its orbit.

Despite Mearsheimer's more objective account on great power politics, his theory also has limitations which is due to the exclusion of domestic variables and not giving agency to small states. This undercuts the theory's ability to produce accurate predictions as it discounts Ukraine's motivation and leaves unanswered how the crisis is viewed from this country's perspective. Ikenberry's Liberal Internationalist theory offers a better perspective on this score. Liberal IR theory, which Ikenberry is a product of, looks inside states in explaining foreign policy processes. In the case of Ukraine, seen through the prism of Liberal Internationalism, Ukraine's determination to sign an association agreement with the EU, rather than participating in the Russia-led EEU, reflects a will to join the liberal international order. Ukraine pursues this 
path because, like the ex-socialist states in Eastern Europe, it is a rational actor, meaning that it concludes that its interests are best served by becoming part of the liberal democratic west. Overall, the way in which the Ukraine crisis has turned out cannot be adequately explained without understanding Ukraine's agency. This country's motivation to distance itself from Russia, which necessitates restoring its territorial integrity and bolstering its ties with the west need to be factored in for a thorough analysis of the Ukraine crisis.

The last part of this work offered an account from the two theories prisms on how to respond to Russia for its actions against Ukraine. Offensive Realist theory asserts that great power competition compels the US, the hegemon in the western hemisphere, to devise policies aimed at containing Russia in its region. However, Mearsheimer considers Russia a declining power and on the basis of this assessment, proposes a solution based on making Ukraine a neutral state. This proposal, however, is at odds with Offensive Realism's basic assumption that states' intentions cannot be known. Even if Ukraine is rendered neutral, given the fact that international system lacks a central authority, a feature that is often highlighted by Mearsheimer, there is no guarantee that Russia will not pursue a revisionist policy against Ukraine in the following years. Regarding the approach to be adopted against Russia via the lens of Liberal Internationalism, this theory would suggest that similar to the liberal nations' embracement of ex-socialist states in Eastern Europe after the Cold War, which enabled the expansion of liberal internationalism, a similar policy must be pursued vis-à-vis Ukraine. This involves providing diplomatic, economic and military support to Ukraine in the latter's attempt to distance itself from Russia and chart its course towards the west. Indeed, despite lacking membership prospect, Ukraine's growing ties with the EU and the NATO as well as the military support it receives from the US indicate the implementation of this policy.

\section{BIBLIOGRAPHY}

(2017) Volker: Hot War Not Frozen Conflict in Donbas (Video). UNIAN, 23 July 2017, https://www.unian.info/war/2044216-volker-hot-war-not-frozen-conflict-in-donbasvideo.html, (06.02.2018).

(2018). NATO’s Support to Ukraine. https://www.nato.int/nato_static_fl2014/assets/pdf/pdf_2018_11/20181106_1811factsheet-nato-ukraine-support-eng.pdf, (26.04.2019).

Brzezinski, Z. (1997). The Grand Chessboard: American Primacy and Its Geostrategic Imperatives. New York: Basic Books. 
Darden, K. (2014). How to Save Ukraine: Why Russia Is Not the Real Problem, Foreign Affairs, 14 April 2014, https://www.foreignaffairs.com/articles/russianfederation/2014-04-14/how-save-ukraine, (16.04.2019).

Fukuyama, F. (1992). The End of History and The Last Man, New York: Free Press.

GDP Ranking, 2016, http://databank.worldbank.org/data/download/GDP.xls, (05.10.2017).

Ikenberry, G. J. (2001a). After Victory, Princeton: Princeton University Press.

Ikenberry, G. J. (2001b). Getting Hegemony Right, The National Interest, 63 (Spring), p. 1724.

Ikenberry, G. J. (2002). America's Imperial Ambition, Foreign Affairs, 81 (5), p. 44-60.

Ikenberry, G. J. (2004). Liberalism and Empire: Logics of Order in American Unipolar Age, Review of International Studies, 30 (4), p. 609-630.

Ikenberry, G. J. (2009a). Introduction: Woodrow Wilson, the Bush Administration, and the Future of Liberal Internationalism, John G. Ikenberry, Thomas J. Knock, AnneMarie Slaughter and Tony Smith, The Crisis of American Foreign Policy, (p. 1-25), Princeton: Princeton University Press.

Ikenberry, G. J. (2009b). Liberal Internationalism 3.0: America and the Dilemmas of Liberal World Order, Perspectives on Politics, 7 (1), p. 71-87.

Ikenberry, G. J. (2011a). Liberal Leviathan, Princeton: Princeton University Press.

Ikenberry, G. J. (2011b). The Liberal Sources of American Unipolarity, J. G. Ikenberry, M. Mastanduno and W. C. Wohlforth (ed.), International Relations Theory and the Consequences of Unipolarity, (p. 216-252), New York: Cambridge University Press.

Ikenberry, G. J. (2014a). The Illusion of Geopolitics: The Enduring Power of the Liberal Order, Foreign Affairs, 93 (3), https://www.foreignaffairs.com/articles/china/201404-17/illusion-geopolitics (13.03.2019).

Ikenberry, G. J. (2014b). The Logic of Order: Westphalia, Liberalism, and the Evolution of International Order in the Modern Era, J. G. Ikenberry (ed.), Power, Order, and Change in World Politics, (p. 83-107), Cambridge: Cambridge University Press.

Ikenberry, G. J. (2015a). The Future of Liberal World Order, Japanese Journal of Political Science, 16 (3), p. 450-455.

Ikenberry, G. J. (2015b). The Future of Multilateralism: Governing the World in a PostHegemonic Era, Japanese Journal of Political Science, 16 (3), p. 399-413.

Ikenberry, G. J, Wohlforth, W. C and Brooks, S. (2012). Don't Come Home, America: The Case against Retrenchment, International Security, 37 (3), p. 7-51.

Johnston, C. (2014). Mikhail Gorbachev: World on Brink of New Cold War over Ukraine. The Guardian. 8 November 2014.

Keohane, O. R. (1984). After Hegemony: World Political Economy Cooperation and Discord, New Jersey: Princeton University Press.

Mearsheimer, J. J. (1990). Back to the Future: Instability in Europe After the Cold War, International Security, 15 (1), p. 5-56.

Mearsheimer, J. J. (1993). The Case for a Ukrainian Nuclear Deterrent, Foreign Affairs, 72 (3), p. 50-66. 
Mearsheimer, J. J. (2006a). China's Unpeaceful Rise, Current History, 105 (690), p. 160-162.

Mearsheimer, J. J. (2006b). Conversations in International Relations: Interview with John J. Mearsheimer (Part I), International Relations, 20 (1), p. 105-123.

Mearsheimer, J. J. (2009). Reckless States and Realism, International Relations, 23 (2), p. 241-256.

Mearsheimer, J. J. (2010a). Structural Realism, Milja Kurki, S. Smith and T. Dunne (ed.), International Relations Theories: Discipline and Diversity, (p. 77-94), Oxford: Oxford University Press.

Mearsheimer, J. J. (2010b). The Gathering Storm: China's Challenge to US Power in Asia, The Chinese Journal of International Politics, (3), p. 381-396.

Mearsheimer, J. J. (2010c). Why is Europe Peaceful Today?, European Political Science, (9), p. 387-397.

Mearsheimer, J. J. (2015). Don't Arm Ukraine, 09 February 2015, New York Times, http://www.nytimes.com/2015/02/09/opinion/dont-arm-ukraine.html?_r=0, (01.03.2019).

Mearsheimer, J. J. (2014a). Conference Call with John Mearsheimer on the Ukraine Crisis, Foreign Affairs, 4 September 2014, https://www.foreignaffairs.com/press/conference-call-john-mearsheimer-ukrainecrisis, (12.04.2019).

Mearsheimer, J. J. (2014b). Getting Ukraine Wrong, The New York Times, 13 March 2014.

Mearsheimer, J. J. (2014c). The Tragedy of Great Power Politics, New York: W. W Norton \& Company.

Mearsheimer, J. J. (2014d). Why the Ukraine Crisis Is the West's Fault: The Liberal Delusions That Provoked Putin, Foreign Affairs, 93 (5), p. 77-89.

Peterson, N. (2018). With US and British Support, Ukraine Pushes Back on Russian Aggression in the Sea of Azov, Daily Signal, 27 September 2018, https://www.dailysignal.com/2018/09/27/with-us-and-british-support-ukrainepushes-back-on-russian-aggression-in-the-sea-of-azov/, (01.05.2019).

Sakwa, R. (2016). Frontline Ukraine: Crisis in the Borderlands, London: I.B. Tauris.

Salimov, O. (2015). Tajikistan Paves the Way to Eurasian Union, 7 January 2015, https://www.cacianalyst.org/publications/field-reports/item/13113-tajikistan-pavesthe-way-to-eurasian-union.html, (08.08.2015).

Nienaber, M. (2019). UPDATE 2-U.S. Warns German Companies of Possible Sanctions over Russian Pipeline, https://af.reuters.com/article/energyOilNews/idAFL8N1ZD0IH, (25.04.2019).

Walt, M. S. (1990). The Origins of Alliances, New York: Cornell University Press.

Waltz, K. N. (1979). Theory of International Politics, Massachusetts: Addison-Wesley Publishing Company.

Where Did Russian Federation Export to in 2016?, http://atlas.cid.harvard.edu/explore/?country=186\&partner=undefined \&product $=u n$ defined \&productClass=HS\&startYear=undefined $\&$ target=Partner \&year=2016, (18.11.2017). 